\title{
Measurement of Metabolic and Inflammatory Serum Markers and Immune Marker Gene Expression during Superovulation in Beef Cattle
}

\author{
Alexandria P. Snider ${ }^{1,2 *}$, Derek J. McLean ${ }^{3}$, Alfred R. Menino ${ }^{3}$ \\ ${ }^{1} 112$ Withycombe Hall, Department of Animal and Rangeland Sciences, Oregon State University, Corvallis, USA \\ ${ }^{2}$ USDA, ARS, U.S. Meat Animal Research Center, Livestock Biosystems Unit, Clay Center, NE, USA \\ ${ }^{3}$ Eunice Kennedy Shriver National Institute of Child Health and Human Development, Bethesda, MD, USA \\ Email: *alex.snider@usda.gov, derek.mclean@nih.gov, Alfred.r.menino@oregonstate.edu
}

How to cite this paper: Snider, A.P., McLean, D.J. and Menino, A.R. (2021) Measurement of Metabolic and Inflammatory Serum Markers and Immune Marker Gene Expression during Superovulation in Beef Cattle. Open Journal of Animal Sciences, 11, 175-196. https://doi.org/10.4236/ojas.2021.112014

Received: December 22, 2020

Accepted: April 12, 2021

Published: April 15, 2021

Copyright $\odot 2021$ by author(s) and Scientific Research Publishing Inc. This work is licensed under the Creative Commons Attribution International License (CC BY 4.0).

http://creativecommons.org/licenses/by/4.0/ (c) (i) Open Access

\begin{abstract}
Health status of donor cows during superovulation is important to ensure optimal embryo quality at time of collection. Because nutritional and metabolic status impact embryo quality some form of nutritional supplementation is often provided before and during superovulation. OmniGen-AF ${ }^{\circledast}(\mathrm{OG})$ feeding has been shown to assist in the maintenance of animal health through regulation of metabolic status and balance and supporting aspects of immune function. We observed feeding donor cows OG decreased percent degenerate embryos recovered following superovulation increased serum progesterone concentration and improved in vitro embryo development. Evaluation of OG feeding on markers of metabolic function and inflammatory and immune function in beef cattle embryo donors are reported here. Similarly, cow metabolic and inflammatory response with repeated superovulation protocols is not known. Biomarkers to monitor and evaluate cow health during superovulation may provide management options to improve embryo recovery and quality. Twenty-four Angus cross-bred cattle were randomly assigned to four treatment groups, fed 0 or $56 \mathrm{~g} / \mathrm{hd} /$ day for 49 days and superovulated with 200 or 400 mg Folltropin V (FSH). Blood was collected weekly for analyses. The protocol was repeated on all cows $90-120 \mathrm{~d}$ later with cows reassigned to their original groups. No differences $(P>0.10)$ were observed due to OG feeding or FSH dose on metabolic and inflammatory markers. Replicate exerted a significant effect where serum concentration of albumin, IL1 $\beta$, IL6, $\mathrm{PGE}_{2}$ and leptin were lower $(P<0.05)$ in Replicate 1 compared to 2 . There was also a similar pattern of change in several of the metabolic and inflam-
\end{abstract}


matory markers during the superovulation protocol where concentrations were higher at the time of estrus and ovulation. Taken together, physiologic changes during the estrous cycle and the number of superovulation protocols can modulate metabolic markers and inflammatory response.

\section{Keywords}

Bovine, Metabolism, Estrous Cycle, Follicle Stimulating Hormone, Inflammation

\section{Introduction}

Embryo collection and transfer are two commonly used assisted reproductive techniques in the cattle industry. These techniques are used to improve herd genetics through the use of genetically desirable dam and sire matings [1]. Embryo collection requires superovulation of the donor cow which involves multiple injections of follicle stimulating hormone to stimulate ovulation of multiple follicles during one cycle. Embryos are frequently collected at day 7 of gestation and either transferred directly or cryopreserved and transferred later into estrus-timed recipients [2].

During superovulation, it is important to reduce potential factors that can cause a decrease in embryo quality. Decreased embryo quality is associated with donor age, nutritional status, stress, and metabolic and health status [3]. For example, donor age has a role in embryo quality as older oocytes may be more susceptible to fertilization failure and early embryonic death. Donor nutritional status is also important as a poor plane of nutrition can decrease body condition score leading to decreased fertilization rates and embryo quality [3].

Nutrition is important in maintaining metabolic function in cattle because poor nutrition decreases metabolic function resulting in disrupted homeostasis, increased stress response and decreased reproductive function [4]. Folliculogenesis, ovulation and early embryonic development rely on proper nutrition and metabolic status due to the nutrient need for follicular growth and endocrine response [5]. Glucose and insulin are important regulators of metabolic status and are important for reproductive function. Dysregulation in insulin response to glucose can cause alterations in ovulation, fertilization and conception success [5]. Other markers of metabolic status are blood urea nitrogen (BUN), nonesterified fatty acids (NEFA), and beta-hydroxybutyrate (BHB). BUN is a product of rumen undegradable protein (RUP) and fluctuates throughout the day [6]. Research has shown a negative impact with increased serum BUN concentrations on overall reproductive performance. NEFA concentrations are an important marker to determine mobilization of fat stores within the body. Reproductive function is correlated with NEFA concentration because when NEFA is elevated there is a negative impact on ovulation and early embryonic development 
[7]. BHB is a ketone body that is also involved with mobilization of fat breakdown and when concentrations are elevated it will also cause a negative impact on reproductive performance [8]. The relationship among these markers of fat and protein mobilization may be a key element of maintaining the nutrient balance required for reproductive function while maintaining an optimal uterine environment during fertilization followed by embryo growth and attachment.

Acute phase proteins (APP), pro-inflammatory cytokines, and other hormones such as prostaglandin $\mathrm{E}_{2}\left(\mathrm{PGE}_{2}\right)$ and leptin have roles in influencing reproductive success. Haptoglobin, serum amyloid A (SAA) and albumin are important APPs because increased serum concentrations are indicative of an inflammatory event [9]. For example, a bacterial infection in the uterus results in the liver increase production of positive APP leading to a decrease in ovulation and fertilization [10]. Pro-inflammatory cytokines, such as interleukin 1-beta (IL1- $\beta$ ) and interleukin 6 (IL6), are also part of the inflammatory response network because increased serum levels lead to the production of APP by the liver [9]. The complexity of the ovulation process results in an ovarian localized inflammatory event and increased concentrations of pro-inflammatory cytokines are important for cellular turnover after ovulation and formation of the corpus luteum [11]. The balance of systemic and localized inflammatory response for efficient reproductive function and cyclicity underscores the need to increase our understanding of the changes in inflammatory biomarkers associated with reproductive function.

$\mathrm{PGE}_{2}$ is involved in early embryonic development as increased concentrations decrease myometrial contractility, a part of the sequence of events that maintains a conducive uterine environment for embryo attachment [12]. Leptin is a key metabolic regulator and is involved with reproduction with neuroendocrine regulation and an increased serum concentration leads to decreases in follicular size and ovulation rates [13]. There are different physiological mechanisms that regulate inflammatory and metabolic markers to support the precise tissue environmental conditions required for fertilization and early embryonic development. One approach commonly used to help to maintain optimal metabolic status is nutritional supplementation. A nutritional supplement shown to modulate metabolic markers during stress is OmniGen- $\mathrm{AF}^{\circledast}$ (OG; Phibro Animal Health, Teaneck, New Jersey).

Research with feeding OG to cattle demonstrated a supportive effect on responses to maintain animal health during periods of stress, such as heat stress and pathogen challenges [14] [15]. The response appears to be linked through regulation of metabolic status and support of aspects of the innate and adaptive immune system [16] [17]. Two specific markers of immune status are interleukin-8 receptor (CXCR2) and L-selectin $(C D 62 L)$ and both are upregulated with OG supplementation [18]. OG feeding can also influence metabolic pathways and maintain overall animal health [19] [20]. Despite the close link between immune function, metabolism and reproductive function, evaluating the effects of OG supplementation on reproductive performance have focused on production measurements in dairy cows [21]. We have demonstrated that feeding OG 
to cows during a superovulation protocol resulted in decreased percentage of degenerate embryos at the time of collection [22]. However, the underlying biological changes to support oocyte quality or embryo development when feeding OG are not known. We hypothesized that differences in metabolic balance and inflammatory factors could lead to altered embryogenesis. Therefore, the objective of this study was to evaluate the effect of feeding OG on markers of metabolic activity and immune status during a superovulation protocol when donors were treated with two different doses of follicle stimulating hormone.

\section{Material and Methods}

\subsection{Animal Care and Use}

All animals were humanely treated and cared for in accordance with Oregon State University IACUC Guidelines.

\subsection{Animal Housing and Feeding}

Cross-bred Angus cows $(n=24)$ were housed in a free stall barn in the Oregon State University Beef Cattle Center in Corvallis, OR with access to ad libitum grass hay and water. Cows were blocked for age and randomly assorted into four treatment groups (six cows per treatment) supplemented with 0 or $56 \mathrm{~g} / \mathrm{OG} /$ animal/day (completely mixed into a mixture of corn and molasses) and treatment with 200 or $400 \mathrm{mg}$ Folltropin $\mathrm{V}^{\circledast}$ (FSH; Bioniche, Athens, GA) as previously described [22]. The duration of the supplementation was $49 \mathrm{~d}$ with a 28 -d pre-feeding phase prior to the start of the superovulation protocol as previously described [22].

\subsection{Estrous Synchronization, Superovulation and Artificial Insemination}

Estrous synchronization, superovulation and artificial insemination protocols used were previously described [22]. Briefly, estrous synchronization was initiated in all cows on Day 28 of the feeding period with a $25-\mathrm{mg}$ i.m. injection of prostaglandin $\mathrm{F}_{2 \alpha}$ (PGF; Lutalyse ${ }^{\varpi}$, Zoetis, Florham Park, NJ). Ten days after the first injection of PGF, cows received a 4-day regimen of FSH within their respective groups. Signs of behavioral estrus were monitored starting $24 \mathrm{~h}$ after the second PGF injection administered on Day 12 and at 12-h intervals thereafter. Cows were artificially inseminated with $0.5 \mathrm{cc}$ of semen at 0,12 , and $24 \mathrm{~h}$ postestrus onset. Cows failing to display signs of behavioral estrus by $36 \mathrm{~h}$ following the second PGF injection were artificially inseminated at 0,12 and $24 \mathrm{~h}$ after the injection. All cows received $100 \mu \mathrm{g}$ of GnRH (Factrel ${ }^{\oplus}$, Zoetis, Florham Park, NJ) at the time of the first artificial insemination.

\subsection{Blood Collection}

Blood samples were collected by jugular venipuncture on Days $0,10,14,21,28$, $38,42,43$, and 49 of the study, as previously described [22]. Briefly, serum sam- 
ples were collected in 10-ml serum separator tubes with and without clot activator and gel (BD Vacutainer systems, Franklin Lakes, NJ). Serum tubes were centrifuged at $3000 \times \mathrm{g}$ for $20 \mathrm{~min}$ at $4^{\circ} \mathrm{C}$ and sera were stored at $-80^{\circ} \mathrm{C}$ until further analysis. Samples for gene expression were collected with Tempus Blood RNA Tubes (Cat. No. 4342792, Thermo Scientific, Waltham, MA). Immediately after blood collection, tubes were shaken vigorously for $15 \mathrm{sec}$ and stored at $-20^{\circ} \mathrm{C}$ until RNA purification (within 3 months).

\subsection{RNA Purification and qPCR Analysis}

RNA was purified using the Tempus Spin RNA Isolation kit (Cat. No. 4380204, Thermo Scientific) following the manufacturer's instructions and upon completion samples were stored at $-80^{\circ} \mathrm{C}$ until RTqPCR. RNA was evaluated for quality and concentration using the Thermo Scientific NanoDrop Lite Spectrophotometer (Cat. No. ND-LITE, Waltham, MA). RNA with an absorbance ratio (260/280 $\mathrm{nm}$ ) above 2.0 was used for analysis. All samples were diluted to $5 \mathrm{ng} / \mu \mathrm{l}$ for RT-qPCR analysis. Each sample was run in duplicate for specific target genes and concentrations were based on a standard curve for each gene. Two target genes of interest were chosen based on previous research of immune regulation with OG supplementation. The target gene markers were interleukin-8 receptor (CXCR2) [23] and L-selectin (CD62L) [15]. All primers were ordered from the pre-designed catalog of bovine primers from ThermoFisher Scientific. The reaction mix per well was as follows: $5 \mu \mathrm{l}$ RA, $9 \mu \mathrm{l}$ RNase/DNase free water (Cat. No. RO582, ThermoFisher Scientific, Grand Island, NY), $5 \mu$ Taqman Fast-Virus Master Mix (Cat. No. 4444434, ThermoFisher Scientific, Carlsbad, CA), and $1 \mu$ target primer. RT-qPCR analysis was conducted in a CFX96 optics unit mounted on a C1000 touch base (BioRad, Hercules, CA). All unknown samples were compared against standard curves created from the probe region of commercially available primer/probe sets (ThermoFisher Scientific). Standard curve constructs and analysis were performed as described by Armstrong (2016) [24].

\subsection{Serum Analysis}

All serum samples were analyzed in duplicate for all targeted endpoints. BUN (Cat. No. K024-H1) and insulin (Cat. No. K046-H1) concentrations were determined by use of a commercially available colorimetric detection kit (Arbor Assays, Ann Arbor, MI) according to the manufacturer's instructions. Intra- and inter-assay coefficients of variation for BUN and insulin were $8.6 \%$ and $12 \%$ and $7.9 \%$ and $10 \%$, respectively. Concentrations of the following markers were determined by the use of commercially available ELISA kits and intra- and inter-assay coefficients of variation were for: $\mathrm{PGE}_{2}$ (Cat. No. EHPGE2, ThermoFisher Scientific, Frederick, MD) $4.6 \%$ and 6.5\%, respectively; leptin (Cat. No. CSB-E06771b, Cusabio, College Park, MD) 6.6\% and 9.7\%, respectively; IL-1 $\beta$ (Cat. No. SEA563Bo, Cloud-Clone Corp, Houston, TX) $8.0 \%$ and $12.0 \%$, respectively; IL-6 (Cat. No. HEA079Bo, Cloud-Clone Corp, Houston, TX) 5.5\% and 
7.6\%, respectively; haptoglobin (Cat. No. MBS564002) 9.16\% and 5.16\%, respectively; and SAA (Cat. No. TP 802, Tridelta, Booton, NJ) were $9.6 \%$ and $10.4 \%$, respectively. Albumin (Cat. No. 0285, Stanbio Laboratory, Boerne, TX) concentrations were determined using a commercially available colorimetric detection kit adapted to be analyzed on a 96-well Corning plate. Intra- and inter-assay coefficients of variation were $8.5 \%$ and $9.4 \%$, respectively. BHB (Cat. No. 2440, Stanbio Laboratory, Boerne, TX) concentration was determined using a commercially available colorimetric detection kit as described by Hall et al. (2014) [25]. Intra- and inter-assay coefficients of variance were $3 \%$ and $9 \%$, respectively. Glucose (Cat. No. 439 - 90,901, Wako Diagnostics, Richmond, VA) and NEFA (Cat. No. 999 - 34,691, 995 - 34,791, 991 - 34,891, 993 - 35,191 and 276 76,491, Wako Diagnostics, Richmond, VA) concentrations were determined with the use of commercially available colorimetric kits and assays were performed as described by Burdick Sanchez et al. (2014). Intra and inter-assay coefficients of variation for glucose and NEFA were $6.3 \%$ and $13.2 \%$ and $5.2 \%$ and $14.5 \%$, respectively.

\subsection{Statistical Analysis}

Repeated measures ANOVA for a $2 \times 2$ factorial design were used to evaluate differences in serum albumin, BHBA, BUN, glucose, haptoglobin, IL1- $\beta$, IL-6, insulin, NEFA, $\mathrm{PGE}_{2}$, leptin and SAA concentrations and $C X C R 2$ and $C D 62 L$ gene expression during the feeding period. Sources of variation in the ANOVA were FSH, OG, Replicate, days of blood collection (Day) and the interactions. If significant effects were observed in the ANOVA differences between means were evaluated using the Fisher's least significant differences procedures. All analyses were performed using the NCSS statistical software program (Number Cruncher Statistical System; 2007, Jerry Hintze, Kaysville, UT).

\section{Results}

\subsection{Metabolic Markers}

Serum BHB concentrations did not differ $(P>0.10)$ by FSH $(200 \mathrm{mg}, 0.32 \mathrm{mmol} / \mathrm{l}$; $400 \mathrm{mg}, 0.33 \mathrm{mmol} / \mathrm{l}$; pooled $\mathrm{SE}=0.01 \mathrm{mmol} / \mathrm{l})$ or $\mathrm{OG}(0 \mathrm{~g}, 0.31 \mathrm{mmol} / \mathrm{l} ; 56 \mathrm{~g}$, $0.34 \mathrm{mmol} / \mathrm{l}$; pooled SE $=0.01 \mathrm{mmol} / \mathrm{l})$ but were higher $(P<0.05)$ in Replicate 1 compared to Replicate $2(0.35 \pm 0.01 \mathrm{mmol} / \mathrm{l}$ vs $0.29 \pm 0.01 \mathrm{mmol} / \mathrm{l}$, respectively). BHB concentrations were lower $(P<0.05)$ on days 0 and 10 compared to days 28 and 38 (Table 1). No other interactions were significant factors affecting serum $\mathrm{BHB}$ concentrations.

Serum BUN concentrations did not differ $(P>0.10)$ by FSH $(200 \mathrm{mg}, 13.6$ $\mathrm{mg} / \mathrm{dl} ; 400 \mathrm{mg}, 15.6 \mathrm{mg} / \mathrm{dl}$; pooled $\mathrm{SE}=1.35 \mathrm{mg} / \mathrm{dl})$ or OG $(0 \mathrm{~g}, 14.2 \mathrm{mg} / \mathrm{dl} ; 56 \mathrm{~g}$, $14.9 \mathrm{mg} / \mathrm{dl}$; pooled SE $=1.35 \mathrm{mg} / \mathrm{dl})$ but were higher $(P<0.05)$ in Replicate 1 compared to Replicate $2(18.2 \pm 0.48 \mathrm{mg} / \mathrm{dl}$ vs $11.0 \pm 0.49 \mathrm{mg} / \mathrm{dl}$, respectively). Day was a significant factor affecting BUN concentrations $(P<0.05)$. Highest serum $(P<0.05)$ BUN concentration was observed on Day 0 compared to other 
days of collection (Table 1). The Replicate $\times$ Day interaction was also a significant factor and BUN concentrations were greater $(P<0.05)$ on Days 14 through 49 in Replicate 1 compared to Replicate 2 (Figure 1). No significant differences in BUN concentrations were observed for any of the other interactions.

Serum glucose concentrations did not differ $(P>0.10)$ by FSH $(200 \mathrm{mg}, 59.6$ $\mathrm{mg} / \mathrm{dl} ; 400 \mathrm{mg}, 59.0 \mathrm{mg} / \mathrm{dl} ;$ pooled $\mathrm{SE}=2.0 \mathrm{mg} / \mathrm{dl})$ or OG $(0 \mathrm{~g}, 59.0 \mathrm{mg} / \mathrm{dl} ; 56 \mathrm{~g}$, $59.4 \mathrm{mg} / \mathrm{dl}$; pooled SE $=2.0 \mathrm{mg} / \mathrm{dl})$ but were higher $(P<0.05)$ in Replicate 1 compared to Replicate $2(61.5 \pm 1.2 \mathrm{mg} / \mathrm{dl}$ vs $56.9 \pm 1.2 \mathrm{mg} / \mathrm{dl}$, respectively). Glucose concentration was lowest $(P<0.05)$ on Day 49 compared to all other sample days and glucose concentration on days 14 and 28 were less $(P<0.05)$ than Day 0 (Table 1$)$. The remaining interactions did not significantly affect serum glucose concentrations.

Table 1. Serum metabolic markers (means \pm SE) measured in cows superovulated with 200 or 400 mg FSH and fed 0 or 56 g OmniGen-AF in Replicate 1 and Replicate 2.

\begin{tabular}{cccccc}
\hline Day & $\begin{array}{c}\text { BHB } \\
(\mathrm{mmol} / \mathrm{L})\end{array}$ & $\begin{array}{c}\text { BUN } \\
(\mathrm{mg} / \mathrm{dl})\end{array}$ & $\begin{array}{c}\text { Glucose } \\
(\mathrm{mg} / \mathrm{dl})\end{array}$ & $\begin{array}{c}\text { Insulin } \\
(\mathrm{pg} / \mathrm{ml})\end{array}$ & $\begin{array}{c}\text { NEFA } \\
(\mathrm{mmol} / \mathrm{l})\end{array}$ \\
\hline 0 & $0.305^{\mathrm{b}}$ & $19.2^{\mathrm{a}}$ & $64.7^{\mathrm{a}}$ & $2425.75^{\mathrm{b}}$ & $0.35^{\mathrm{b}}$ \\
10 & $0.284^{\mathrm{b}}$ & $14.7^{\mathrm{b}}$ & $60.6^{\mathrm{a}, \mathrm{b}}$ & $2234.17^{\mathrm{b}}$ & $0.23^{\mathrm{c}}$ \\
14 & $0.320^{\mathrm{a}, \mathrm{b}}$ & $14.1^{\mathrm{b}}$ & $57.9^{\mathrm{b}}$ & $2250.1^{\mathrm{b}}$ & $0.18^{\mathrm{c}}$ \\
28 & $0.357^{\mathrm{a}}$ & $13.6^{\mathrm{b}}$ & $57.8^{\mathrm{b}}$ & $2345.8^{\mathrm{b}}$ & $0.18^{\mathrm{c}}$ \\
38 & $0.352^{\mathrm{a}}$ & $14.4^{\mathrm{b}}$ & $59.8^{\mathrm{a}, \mathrm{b}}$ & $2917.44^{\mathrm{a}, \mathrm{b}}$ & $0.23^{\mathrm{c}}$ \\
42 & $0.320^{\mathrm{a}, \mathrm{b}}$ & $13.5^{\mathrm{b}}$ & $63.8^{\mathrm{a}, \mathrm{b}}$ & $3247.2^{\mathrm{a}}$ & $0.41^{\mathrm{a}, \mathrm{b}}$ \\
43 & $0.320^{\mathrm{a}, \mathrm{b}}$ & $12.4^{\mathrm{b}}$ & $58.8^{\mathrm{a}, \mathrm{b}}$ & $2704.33^{\mathrm{a}, \mathrm{b}}$ & $0.42^{\mathrm{a}}$ \\
49 & $0.312^{\mathrm{a}, \mathrm{b}}$ & $14.5^{\mathrm{b}}$ & $50.3^{\mathrm{c}}$ & $2735.8^{\mathrm{a}, \mathrm{b}}$ & $0.2^{\mathrm{c}}$ \\
\hline Pooled SE & $0.02^{2}$ & 1.0 & 2.4 & 248.91 & 0.03 \\
\hline
\end{tabular}

${ }^{\mathrm{a}, \mathrm{b}, \mathrm{c}}$ Means in the same column without similar superscripts differ $(P<0.05)$.

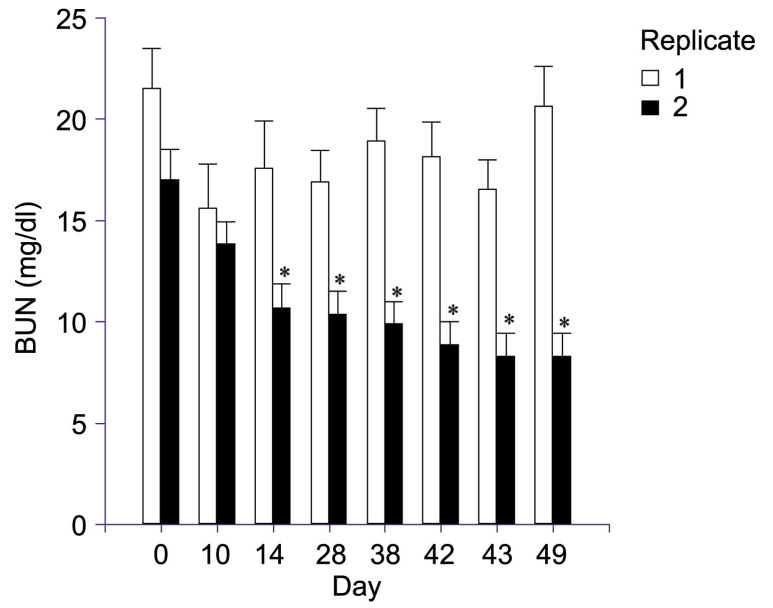

Figure 1. Serum BUN concentrations (means \pm SE) from cows superovulated with 200 or $400 \mathrm{mg}$ FSH and fed 0 or $56 \mathrm{~g}$ OmniGen-AF in Replicate 1 or Replicate 2; ${ }^{\star}$ Different from BUN concentrations in Replicate 1. 
Serum insulin concentration did not differ $(P>0.10)$ by FSH $(200 \mathrm{mg}, 2818$ $\mathrm{pg} / \mathrm{ml} ; 400 \mathrm{mg}, 2397 \mathrm{pg} / \mathrm{ml}$; pooled SE = $274 \mathrm{pg} / \mathrm{ml}), \mathrm{OG}(0 \mathrm{~g}, 2499 \mathrm{pg} / \mathrm{ml} ; 56 \mathrm{~g}$, $2717 \mathrm{pg} / \mathrm{ml}$; pooled SE $=274 \mathrm{pg} / \mathrm{ml})$ or Replicate $(1,2690 \pm 124 \mathrm{pg} / \mathrm{ml} ; 2,2525 \pm$ $125 \mathrm{pg} / \mathrm{ml})$. Day was a significant factor $(P<0.05)$ where insulin concentration was greater on Day 42 compared to Days $0,10,14$ and 28 (Table 1). The FSH $\times$ Replicate interaction was a significant factor where insulin concentration was lowest $(P<0.05)$ in cows injected with $400 \mathrm{mg} \mathrm{FSH}$ in Replicate $2(2110 \pm 176$ $\mathrm{pg} / \mathrm{ml}$ ) compared to cows injected with $200 \mathrm{mg}$ or $400 \mathrm{mg}$ FSH in Replicate 1 $(2696 \mathrm{pg} / \mathrm{ml}$ and $2684 \mathrm{pg} / \mathrm{ml}$, respectively; pooled SE $=176 \mathrm{pg} / \mathrm{ml})$ and cows injected with $200 \mathrm{mg}$ FSH in Replicate $2(2939 \pm 176$ pg/ml). The OG $\times$ Replicate interaction was also a significant factor where insulin concentration was lower in cows fed $0 \mathrm{~g}$ OG in Replicate 2 compared to cows fed $0 \mathrm{~g}$ OG in Replicate 1 and $56 \mathrm{~g}$ OG in Replicate $2(2185 \mathrm{pg} / \mathrm{ml}$ vs 2812 and $2864 \mathrm{pg} / \mathrm{ml}$, respectively; pooled $\mathrm{SE}=176 \mathrm{pg} / \mathrm{ml})$. No significant differences were observed in insulin concentration for any of the remaining interactions.

Serum NEFA concentrations did not differ by FSH (200 mg, $0.28 \mathrm{mmol} / \mathrm{l} ; 400$ $\mathrm{mg}, 0.27 \mathrm{mmol} / \mathrm{l}$; pooled SE $=0.03 \mathrm{mmol} / \mathrm{l})$, OG $(0 \mathrm{~g}, 0.27 \mathrm{mmol} / \mathrm{l} ; 400 \mathrm{mg}, 0.27$ $\mathrm{mmol} / \mathrm{l}$; pooled SE $=0.03 \mathrm{mmol} / \mathrm{l})$ and Replicate $(1,0.28 \pm 0.01 \mathrm{mmol} / \mathrm{l} ; 2,0.27 \pm$ $0.01 \mathrm{mmol} / \mathrm{l}$, respectively). NEFA concentrations differed by Day and were greater $(P<0.05)$ on Days 0,42 and 43 compared to Days 10, 14, 28, 38 and 49 (Table 1). The FSH $x$ OG interaction was a significant factor where NEFA concentrations were lower $(P<0.05)$ in cows fed $56 \mathrm{~g}$ and superovulated with 400 $\mathrm{mg} \mathrm{FSH}$ and cows fed $0 \mathrm{~g}$ OG and superovulated with $200 \mathrm{mg}$ FSH $(0.22$ and $0.24 \mathrm{mmol} / \mathrm{l}$, respectively; pooled $\mathrm{SE}=0.05 \mathrm{mmol} / \mathrm{l}$ ) compared to cows fed $0 \mathrm{~g}$ OG and superovulated with $400 \mathrm{mg}$ FSH and fed $56 \mathrm{~g}$ OG and superovulated with $200 \mathrm{mg} \mathrm{FSH}(0.31$ and $0.33 \mathrm{mmol} / \mathrm{l}$, respectively, pooled $\mathrm{SE}=0.05 \mathrm{mmol} / \mathrm{l})$. The FSH $\times$ Replicate interaction was a significant factor where NEFA concentration was greater $(P<0.05)$ in cows superovulated with $200 \mathrm{mg}$ FSH in Replicate $1(0.31 \pm 0.02 \mathrm{mmol} / \mathrm{l})$ compared to cows in Replicate 2 and cows in Replicate 1 superovulated with $400 \mathrm{mg} \mathrm{FSH}(0.26 \pm 0.02$ and $0.24 \pm 0.02 \mathrm{mmol} / \mathrm{l}$, respectively) but was similar $(P>0.10)$ to cows superovulated with $400 \mathrm{mg}$ FSH in Replicate $2(0.29 \pm 0.02 \mathrm{mmol} / \mathrm{l})$. There was a Replicate $\times$ Day interaction observed on Day 43 where NEFA concentration was lower in Replicate 2 compared to Replicate 1 (Figure 2(a)). The OG $\times$ FSH $\times$ Day interaction was also significant (Figure 2(b)). NEFA concentrations were greater $(P<0.05)$ in cows fed $0 \mathrm{~g} \mathrm{OG}$ and superovulated with $400 \mathrm{mg}$ FSH compared to cows fed $56 \mathrm{~g}$ OG and superovulated with $400 \mathrm{mg}$ FSH on Days 0 and 42 (Figure 2(b)). NEFA concentration was also greater $(P<0.05)$ in cows fed $56 \mathrm{~g}$ OG and superovulated with $200 \mathrm{mg}$ FSH compared to cows fed $0 \mathrm{~g}$ OG and superovulated with $200 \mathrm{mg}$ FSH and cows fed $56 \mathrm{~g}$ OG or superovulated with $400 \mathrm{mg}$ FSH (Figure 2(b)). The remaining interactions were not significant factors affecting serum NEFA concentrations.

\subsection{Pro-Inflammatory Cytokines}

Serum IL1- $\beta$ concentrations did not differ $(P>0.10)$ by FSH $(200 \mathrm{mg}, 976.6$ 
$\mathrm{pg} / \mathrm{ml} ; 400 \mathrm{mg}, 1378.6 \mathrm{pg} / \mathrm{ml}$; pooled $\mathrm{SE}=305.3 \mathrm{pg} / \mathrm{ml})$, or OG $(0 \mathrm{~g}, 1156.6$ $\mathrm{pg} / \mathrm{ml} ; 400 \mathrm{mg}, 1198.6 \mathrm{pg} / \mathrm{ml}$; pooled SE $=305.3 \mathrm{pg} / \mathrm{ml})$, but were lower $(P<$ $0.05)$ in Replicate 1 compared to Replicate $2(657.4 \pm 51.8 \mathrm{pg} / \mathrm{ml}$ vs $1697.8 \pm$ $151.5 \mathrm{pg} / \mathrm{ml}$, respectively). IL1 $\beta$ concentrations were greater $(P<0.05)$ on Day 49 compared to Days 0 through 42 (Table 2). The FSH $\times$ Replicate interaction was significant. IL1- $\beta$ was greater $(P<0.05)$ in cows superovulated with $400 \mathrm{mg}$ FSH in Replicate $2(2072.0 \pm 122.4 \mathrm{pg} / \mathrm{ml})$ compared to all other treatments. IL1- $\beta$ was greater $(\mathrm{P}<0.05)$ in cows superovulated with $200 \mathrm{mg}$ FSH in Replicate 2 compared to cows superovulated with $200 \mathrm{mg}$ and $400 \mathrm{mg}$ FSH in Replicate 1 (1323.6 vs 629.7 and $685.2 \mathrm{pg} / \mathrm{ml}$, respectively; pooled SE $=122.4 \mathrm{pg} / \mathrm{ml})$. The OG $\times$ FSH $\times$ Replicate interaction was also significant where IL1- $\beta$ was greater $(P<0.05)$ in cows fed $0 \mathrm{~g} \mathrm{OG}$ and superovulated with $400 \mathrm{mg} \mathrm{FSH}$ and cows fed 56 g OG and superovulated with 200 or 400 mg FSH in Replicate 2 compared to all other treatments (Figure 2(a)). No significant differences were observed for IL1- $\beta$ for any of the remaining interactions.

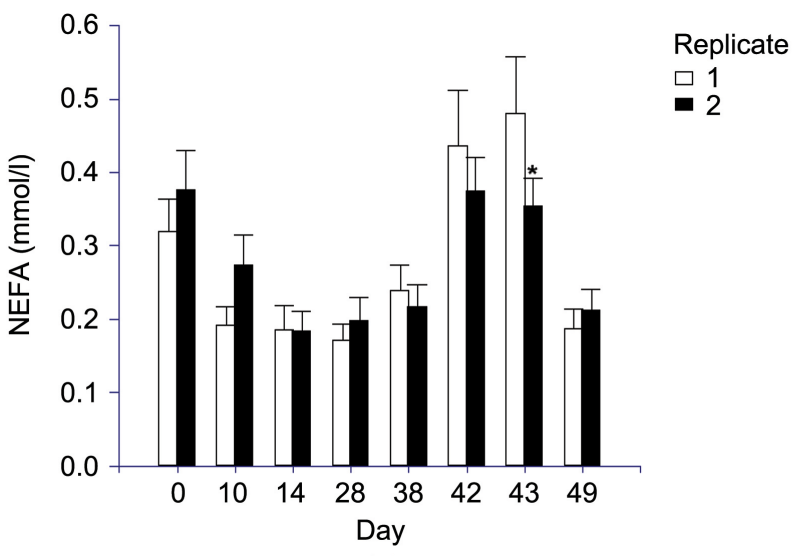

(a)

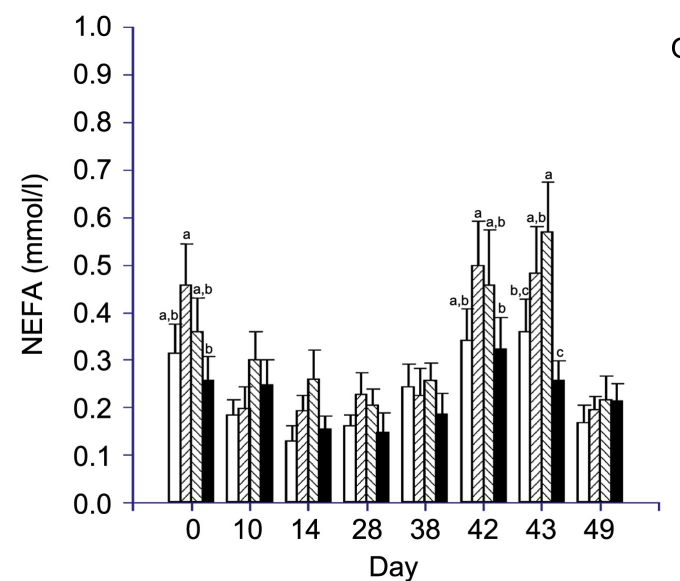

OminGen-AF ${ }^{\circledR}(\mathrm{g}) / \mathrm{FSH}(\mathrm{mg})$

ㅁ 0/200

曰 $0 / 400$

$\otimes 56 / 200$

- 56/400

(b)

Figure 2. (a) Serum NEFA concentrations (means \pm SE) from cows superovulated with 200 or $400 \mathrm{mg}$ FSH and fed 0 or 56 g OmniGen-AF in Replicate 1 or Replicate 2. (b) Serum NEFA concentrations (means \pm SE) from cows superovulated with 200 or $400 \mathrm{mg}$ FSH and fed 0 or $56 \mathrm{~g}$ OmniGen-AF in Replicate 1 and 2; ${ }^{\star}$ Different from NEFA concentrations in Replicate $1{ }^{\mathrm{a}, \mathrm{b}, \mathrm{c}}$ Means without similar letters differ $(P<0.05)$. 
Table 2. Serum pro-inflammatory cytokines (means \pm SE) measured in cows superovulated with 200 or $400 \mathrm{mg}$ FSH and fed 0 or 56 g OmniGen-AF in Replicate 1 and Replicate 2 .

\begin{tabular}{ccc}
\hline Day & IL1- $\beta(\mathrm{pg} / \mathrm{ml})$ & IL-6 $(\mathrm{pg} / \mathrm{ml})$ \\
\hline 0 & $999.5^{\mathrm{b}}$ & $117.5^{\mathrm{b}, \mathrm{c}}$ \\
10 & $1152.9^{\mathrm{b}}$ & $146.9^{\mathrm{a}}$ \\
14 & $970.5^{\mathrm{b}}$ & $113.2^{\mathrm{b}, \mathrm{c}, \mathrm{d}}$ \\
28 & $1119.3^{\mathrm{b}}$ & $115.3^{\mathrm{b}, \mathrm{c}, \mathrm{d}}$ \\
38 & $1077.8^{\mathrm{b}}$ & $119^{\mathrm{a}, \mathrm{b}, \mathrm{c}}$ \\
42 & $946.5^{\mathrm{b}}$ & $87.9^{\mathrm{d}}$ \\
43 & $1358.2^{\mathrm{a}, \mathrm{b}}$ & $96^{\mathrm{b}, \mathrm{c}, \mathrm{d}}$ \\
49 & $1795.9^{\mathrm{a}}$ & $134.1^{\mathrm{a}, \mathrm{b}}$ \\
Pooled SE & 172.2 & 10.3 \\
\hline
\end{tabular}

${ }_{\mathrm{a}, \mathrm{b}, \mathrm{c}, \mathrm{d}}$ Means in the same column without similar superscripts differ $(P<0.05)$.

Serum IL-6 concentrations tended to be lower $(P=0.09)$ in cows superovulated with 200 compared to $400 \mathrm{mg}$ FSH $(98.8 \mathrm{pg} / \mathrm{ml}$ vs. $133.6 \mathrm{pg} / \mathrm{ml}$, respectively; pooled $\mathrm{SE}=14.1 \mathrm{pg} / \mathrm{ml}$ ), but no differences were observed due to OG feeding $(0 \mathrm{~g}, 111.3 \mathrm{pg} / \mathrm{ml} ; 400 \mathrm{mg}, 133.7 \mathrm{pg} / \mathrm{ml}$; pooled SE = $14.1 \mathrm{pg} / \mathrm{ml})$. Cows in Replicate 1 tended to have lower $(P=0.08)$ IL- 6 serum concentrations compared to Replicate $2(109.9 \pm 5.1 \mathrm{pg} / \mathrm{ml}$ vs $122.5 \pm 5.2 \mathrm{pg} / \mathrm{ml}$, respectively). IL-6 concentrations were greatest $(P<0.05)$ on Days 10 and 49 and lowest $(P<0.05)$ on Days 42 and 43 (Table 2). The OG $\times$ Replicate interaction was significant. IL-6 concentrations were greatest $(P<0.05)$ in cows fed $56 \mathrm{~g}$ OG in Replicate 2 compared to cows fed $0 \mathrm{~g}$ or $56 \mathrm{~g}$ OG in Replicate 1 and cows fed $0 \mathrm{~g}$ OG in Replicate $2(134.0$ vs 111.5 or 108.3 and $111.1 \mathrm{pg} / \mathrm{ml}$, respectively; pooled $\mathrm{SE}=7.3 \mathrm{pg} / \mathrm{ml})$. The OG $\times$ FSH $\times$ Replicate interaction was also significant. IL- 6 concentrations were greater $(P<0.05)$ in cows fed $0 \mathrm{~g}$ OG and superovulated with $400 \mathrm{mg}$ FSH in Replicate 1 and in Replicate 2 and in cows fed $56 \mathrm{~g}$ OG and superovulated with 200 or $400 \mathrm{mg}$ FSH in Replicate 2 compared to cows fed $0 \mathrm{~g}$ OG and superovulated with $200 \mathrm{mg}$ FSH in Replicates 1 and 2 (Figure 3(b)). The remaining interactions were not significant factors affecting serum IL-6 concentrations.

\subsection{Proteins}

Serum albumin did not differ $(P>0.10)$ by FSH $(200 \mathrm{mg}, 42.2 \mathrm{pg} / \mathrm{ml} ; 400 \mathrm{mg}$, $43.7 \mathrm{pg} / \mathrm{ml}$; pooled SE $=2.28 \mathrm{pg} / \mathrm{ml})$ or OG $(0 \mathrm{~g}, 42.6 \mathrm{pg} / \mathrm{ml} ; 56 \mathrm{~g}, 43.3 \mathrm{pg} / \mathrm{ml}$; pooled SE $=2.28 \mathrm{pg} / \mathrm{ml})$, but was lower $(P<0.05)$ in Replicate 1 compared to Replicate $2(40.1 \pm 0.78 \mathrm{pg} / \mathrm{ml}$ vs $45.8 \pm 0.79$, respectively). Albumin concentration was lower $(P<0.05)$ on Day 0 compared to Days 28 and 42 and on Day 42 was greater $(P<0.05)$ than Days 10,14, 38 and 43 and 49 (Table 3$)$. Both the FSH $\times$ Replicate and OG $\times$ Replicate interactions were significant. Albumin 
concentrations were lower $(P<0.05)$ in cows superovulated with 200 or $400 \mathrm{mg}$ FSH in Replicate 1 compared to cows superovulated with either dose in Replicate 2 and were less $(P<0.05)$ in cows superovulated in Replicate 2 with 200 compared to $400 \mathrm{mg}$ FSH ( 40.6 or 39.7 vs 43.8 vs $47.8 \mathrm{mg} / \mathrm{dl}$, respectively; pooled $\mathrm{SE}=1.1 \mathrm{mg} / \mathrm{dl})$. Albumin concentrations were lower $(P<0.05)$ in cows fed 0 or $56 \mathrm{~g}$ in Replicate 1 and cows fed $0 \mathrm{~g}$ OG in Replicate 2 compared to cows fed $56 \mathrm{~g}$ OG in Replicate 2 (41.3, 39.0, 43.9 vs $47.6 \mathrm{mg} / \mathrm{dl}$, respectively; pooled SE 1.1 $\mathrm{mg} / \mathrm{dl})$. Albumin concentrations were also lower $(P<0.05)$ in cows fed $56 \mathrm{~g}$ OG in Replicate 1 compared to cows fed $0 \mathrm{~g}$ OG in Replicate 2. No significant differences were observed for albumin in any of the remaining interactions.

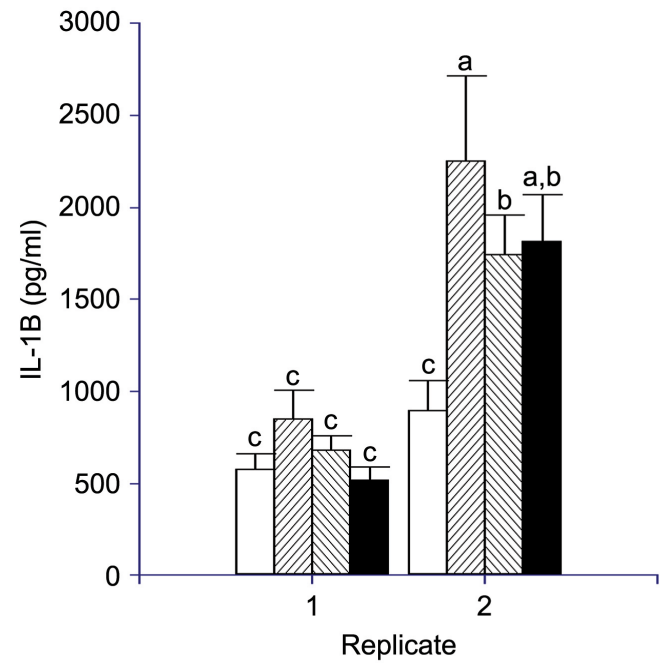

OminGen-AF ${ }^{\circledast}(\mathrm{g}) / \mathrm{FSH}(\mathrm{mg})$

$\square$ 0/200

$\square 0 / 400$

$\nabla 56 / 200$

- 56/400

(a)

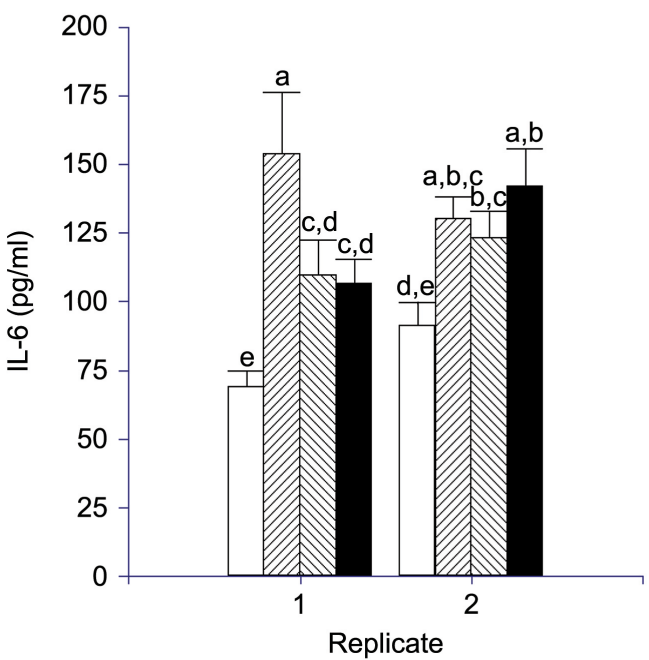

OminGen-AF ${ }^{\circledR}(\mathrm{g}) / \mathrm{FSH}(\mathrm{mg})$

$\square$ 0/200

$\square 0 / 400$

$\triangle 56 / 200$

- 56/400

(b)

Figure 3. Serum Pro-inflammatory cytokines from cows superovulated with 200 or 400 mg FSH and fed 0 or 56 g OmniGen-AF in Replicates 1 and 2. (a) Serum IL1- $\beta$ concentrations (means \pm SE) from cows superovulated with 200 or $400 \mathrm{mg} \mathrm{FSH}$ and fed 0 or $56 \mathrm{~g}$ OmniGen-AF in Replicates 1 and 2. (b) Serum IL-6 concentrations (means \pm SE) from cows superovulated with 200 or $400 \mathrm{mg}$ FSH and fed 0 or 56 g OmniGen-AF in Replicates 1 and 2 ; ${ }^{\mathrm{a}, \mathrm{b}, \mathrm{d}, \mathrm{e}}$ Means in the same column without similar superscripts $\operatorname{differ}(P<0.05)$. 
Table 3. Serum acute phase proteins (means \pm SE) measured in cows superovulated with 200 or $400 \mathrm{mg}$ FSH and fed 0 or $56 \mathrm{~g}$ OmniGen-AF in Replicate 1 and 2.

\begin{tabular}{cccc}
\hline Day & Albumin $(\mathrm{mg} / \mathrm{dl})$ & Haptoglobin $(\mathrm{ng} / \mathrm{ml})$ & SAA $(\mu \mathrm{l} / \mathrm{ml})$ \\
\hline 0 & $39.7^{\mathrm{c}}$ & $12777.3^{\mathrm{a}}$ & $48.3^{\mathrm{b}}$ \\
10 & $41.8^{\mathrm{b}, \mathrm{c}}$ & $2068.2^{\mathrm{b}}$ & $38.1^{\mathrm{b}, \mathrm{c}}$ \\
14 & $42.6^{\mathrm{b}, \mathrm{c}}$ & $5607.6^{\mathrm{a}, \mathrm{b}}$ & $30^{\mathrm{c}, \mathrm{d}}$ \\
28 & $45.1^{\mathrm{a}, \mathrm{b}}$ & $828.3^{\mathrm{b}}$ & $14^{\mathrm{d}}$ \\
38 & $42.1^{\mathrm{b}, \mathrm{c}}$ & $1748^{\mathrm{b}}$ & $20^{\mathrm{d}}$ \\
42 & $47.9^{\mathrm{a}}$ & $2644.3^{\mathrm{b}}$ & $42.3^{\mathrm{b}, \mathrm{c}}$ \\
43 & $42.2^{\mathrm{b}, \mathrm{c}}$ & $13164.7^{\mathrm{a}}$ & $80.7^{\mathrm{a}}$ \\
49 & $42.3^{\mathrm{b}, \mathrm{c}}$ & $6812.3^{\mathrm{a}, \mathrm{b}}$ & $29.5^{\mathrm{c}, \mathrm{d}}$ \\
Pooled SE & 1.6 & 3013.7 & 6.2 \\
\hline
\end{tabular}

${ }_{\mathrm{a}, \mathrm{b}, \mathrm{c}, \mathrm{d}}$ Means in the same column without similar superscripts differ $(P<0.05)$.

Serum haptoglobin did not differ $(P>0.10)$ by FSH $(200 \mathrm{mg}, 4443.4 \mathrm{ng} / \mathrm{ml}$; $400 \mathrm{mg}, 6969.2 \mathrm{ng} / \mathrm{ml}$; pooled SE = $1582.6 \mathrm{ng} / \mathrm{ml})$, OG $(0 \mathrm{~g}, 4913.1 \mathrm{ng} / \mathrm{ml} ; 56 \mathrm{~g}$, $6499.6 \mathrm{ng} / \mathrm{ml}$; pooled SE $=1582.6 \mathrm{ng} / \mathrm{ml})$ or Replicate $(1 \mathrm{vs} 2 ; 6362.1 \pm 1502.4$ $\mathrm{ng} / \mathrm{ml}$ vs $5050.6 \pm 1510.4 \mathrm{ng} / \mathrm{ml}$, respectively). Haptoglobin concentrations were greater $(P<0.05)$ on Days 0 and 43 compared to Days 10, 28, 38 and 42 (Table $3)$. The remaining interactions were not significant factors affecting serum haptoglobin concentrations.

Serum SAA concentrations did not differ $(P>0.10)$ by FSH $(200 \mathrm{mg}, 33.6$ $\mu \mathrm{l} / \mathrm{ml} ; 400 \mathrm{mg} 42.1 \mu \mathrm{l} / \mathrm{ml}$; pooled $\mathrm{SE}=3.7 \mu \mathrm{l} / \mathrm{ml})$, OG $(0 \mathrm{~g}, 37.6 \mu \mathrm{l} / \mathrm{ml} ; 56 \mathrm{~g}, 38.1$ $\mu \mathrm{l} / \mathrm{ml}$; pooled $\mathrm{SE}=3.7 \mu \mathrm{l} / \mathrm{ml})$ and Replicate $(1 \mathrm{vs} 2 ; 38.7 \pm 3.1 \mu \mathrm{l} / \mathrm{ml}$ vs $37.0 \pm 3.1$ $\mu \mathrm{l} / \mathrm{ml}$, respectively). SAA concentration was greatest $(P<0.05)$ on Day 43 and was greater $(P<0.05)$ on Days 0,10 and 42 compared to Days 28 and 38 (Table 3). The Replicate $\times$ Day interaction was significant where SAA concentration was less on Day 14 in Replicate 1 compared to Replicate 2 and was greater on Day 43 in Replicate 1 compared to Replicate 2 (Figure 4). No significant differences in serum SAA concentrations were observed for the remaining interactions.

Serum leptin concentrations did not differ $(P>0.10)$ by FSH $(200 \mathrm{mg}, 7.2$ $\mathrm{ng} / \mathrm{ml} ; 400 \mathrm{mg}, 7.4 \mathrm{ng} / \mathrm{ml}$; pooled SE $=0.27 \mathrm{ng} / \mathrm{ml})$ or OG $(0 \mathrm{~g}, 7.4 \mathrm{ng} / \mathrm{ml} ; 56 \mathrm{~g}$ $7.3 \mathrm{ng} / \mathrm{ml}$; pooled SE $=0.27 \mathrm{ng} / \mathrm{ml})$ but were less $(P<0.05)$ in Replicate 1 compared to Replicate $2(6.8 \pm 0.15 \mathrm{ng} / \mathrm{ml}$ vs $7.9 \pm 0.15 \mathrm{ng} / \mathrm{ml}$, respectively). Leptin concentrations did not differ by Day (Table 4). No significant differences in serum leptin were observed for any of the interactions.

\section{4. $\mathrm{PGE}_{2}$}

Serum $\mathrm{PGE}_{2}$ concentrations did not differ $(P>0.10)$ by FSH $(200 \mathrm{mg}, 913 \mathrm{pg} / \mathrm{ml}$; $400 \mathrm{mg}, 651 \mathrm{pg} / \mathrm{ml}$; pooled SE $=193 \mathrm{pg} / \mathrm{ml})$ or OG $(0 \mathrm{~g}, 719 \mathrm{pg} / \mathrm{ml} ; 56 \mathrm{~g} 845$ 
$\mathrm{pg} / \mathrm{ml}$; pooled SE $=193 \mathrm{pg} / \mathrm{ml})$ but were less $(P<0.05)$ in Replicate 1 compared to Replicate $2\left(489 \pm 109 \mathrm{pg} / \mathrm{ml}\right.$ vs $1075 \pm 110 \mathrm{pg} / \mathrm{ml}$, respectively). $\mathrm{PGE}_{2}$ concentrations did not differ $(P>0.10)$ by Day (Table 5$)$. The OG $\times$ FSH interaction was significant where serum $\mathrm{PGE}_{2}$ was greater $(P<0.05)$ in cows fed $56 \mathrm{~g}$ OG and superovulated with $200 \mathrm{mg}$ FSH compared to cows fed $56 \mathrm{~g} \mathrm{OG}$ and superovulated with $400 \mathrm{mg}$ FSH and cows fed $0 \mathrm{~g}$ OG and superovulated with 200 $\mathrm{mg}$ FSH (Figure 5). The OG $\times$ FSH $\times$ Replicate interaction was also significant where $\mathrm{PGE}_{2}$ was greatest $(P<0.05)$ in Replicate 2 cows fed $56 \mathrm{~g}$ OG and superovulated with $200 \mathrm{mg}$ FSH compared to Replicate 1 cows fed $0 \mathrm{~g}$ OG and superovulated with either $200 \mathrm{mg}$ or $400 \mathrm{mg}$ FSH and cows fed $56 \mathrm{~g}$ OG and superovulated with $400 \mathrm{mg}$ FSH (Figure 5). No significant differences in serum $\mathrm{PGE}_{2}$ were observed for the remaining interactions

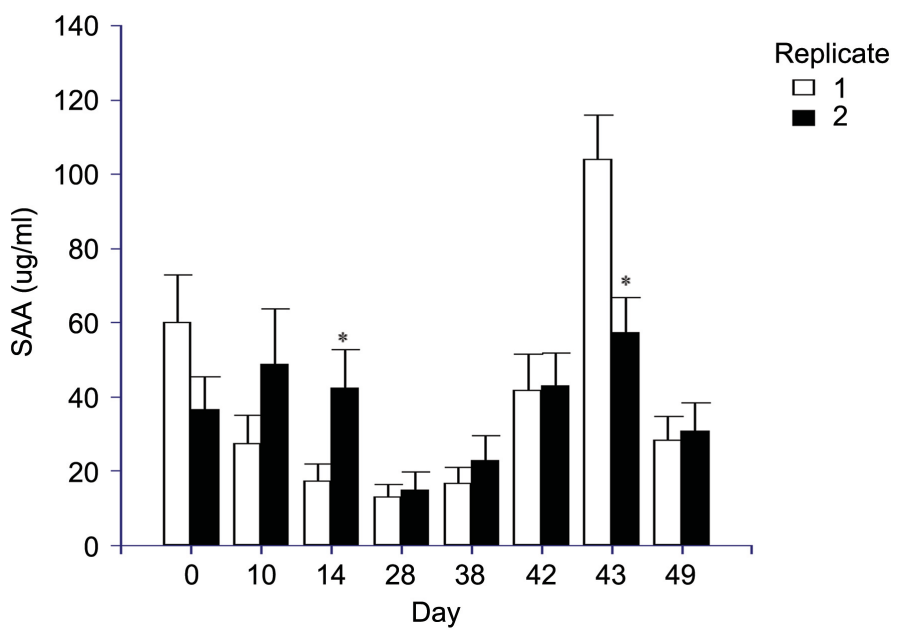

Figure 4. Serum SAA concentrations (means \pm SE) from cows superovulated with 200 or $400 \mathrm{mg}$ FSH and fed 0 or $56 \mathrm{~g}$ OmniGen-AF in Replicate 1 or Replicate 2; ${ }^{\star}$ Different from SAA concentrations in Replicate 1.

Table 4. Serum leptin (means \pm SE) measured in cows superovulated with 200 or $400 \mathrm{mg}$ FSH and fed 0 or $56 \mathrm{~g}$ OmniGen-AF in Replicate 1 and 2.

\begin{tabular}{cc} 
Day & Leptin $(\mathrm{ng} / \mathrm{ml})$ \\
\hline 0 & 7 \\
10 & 7.2 \\
14 & 8 \\
28 & 7.6 \\
38 & 7.1 \\
42 & 7.1 \\
43 & 7.4 \\
49 & 7.2 \\
Pooled SE & 0.31
\end{tabular}




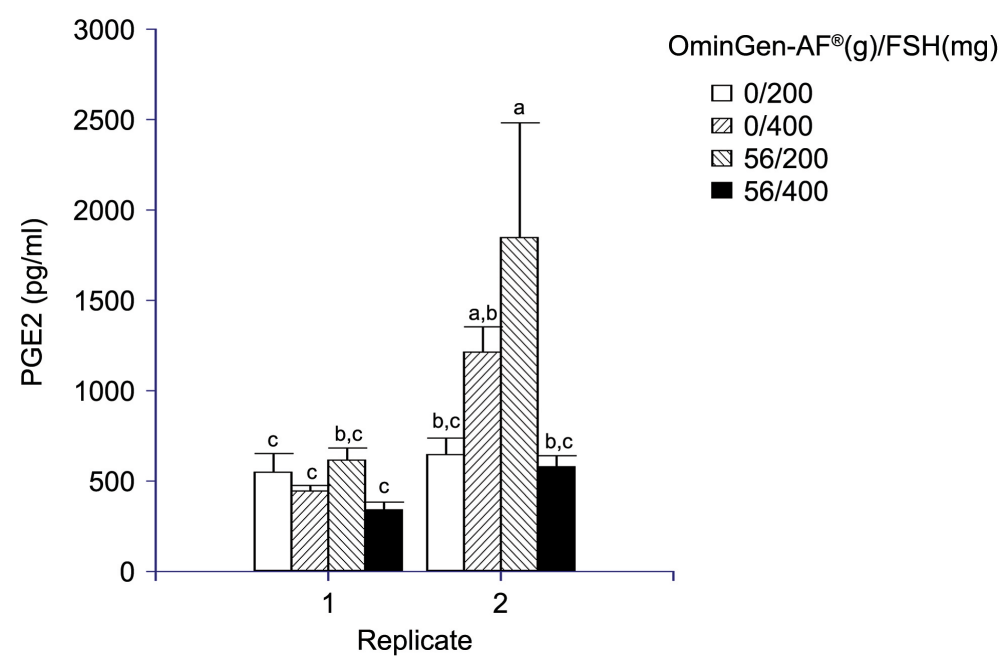

Figure 5. Serum $\mathrm{PGE}_{2}$ concentrations (means $\pm \mathrm{SE}$ ) from cows superovulated with 200 or $400 \mathrm{mg} \mathrm{FSH}$ and fed 0 or $56 \mathrm{~g}$ OmniGen-AF in Replicates 1 and 2; ${ }^{\mathrm{a}, \mathrm{b}, \mathrm{c}}$ Means without similar superscripts differ $(P<0.05)$.

Table 5. Serum $\mathrm{PGE}_{2}$ (means \pm SE) measured in cows superovulated with 200 or $400 \mathrm{mg}$ FSH and fed 0 or $56 \mathrm{~g}$ OmniGen-AF in Replicates 1 and 2.

\begin{tabular}{cc}
\hline Day & $\mathrm{PGE}_{2}(\mathrm{pg} / \mathrm{ml})$ \\
\hline 0 & 1323 \\
10 & 654 \\
28 & 602 \\
38 & 622 \\
42 & 679 \\
43 & 803 \\
49 & 594 \\
Pooled SE & 977 \\
\hline
\end{tabular}

\subsection{Gene Expression}

Expression of CXCR2 in circulating immune cells did not differ $(P>0.10)$ by FSH (200 mg vs $400 \mathrm{mg}$, 9.0 vs 9.3 copies/ $\mu$ g, respectively; pooled $\mathrm{SE}=0.8$ copies $/ \mu \mathrm{g}$ ) or OG (0 g vs $56 \mathrm{~g}, 8.1$ vs 10.3 copies $/ \mu \mathrm{g}$, respectively; pooled $\mathrm{SE}=0.8$ copies $/ \mu \mathrm{g})$. CXCR2 expression was lower $(P<0.05)$ in Replicate 1 compared to Replicate 2 (5.8 vs 12.6 copies $/ \mu \mathrm{g}$, respectively; pooled $\mathrm{SE}=0.4 \mathrm{copies} / \mu \mathrm{g})$. Upregulation of $C X C R 2$ expression was greatest $(P<0.05)$ on Day 42 and greater $(P<0.05)$ on Day 49 compared to Days $0,10,14,21$, and 38 (Table 6). The OG $\times$ Replicate interaction was also significant and $C X C R 2$ expression was greatest $(P<0.05)$ in cows fed $56 \mathrm{~g} \mathrm{OG}$ in Replicate 2 and was greater $(P<0.05)$ in cows fed $0 \mathrm{~g}$ OG in Replicate 2 compared to cows in Replicate 1 (Figure 6(a)). 


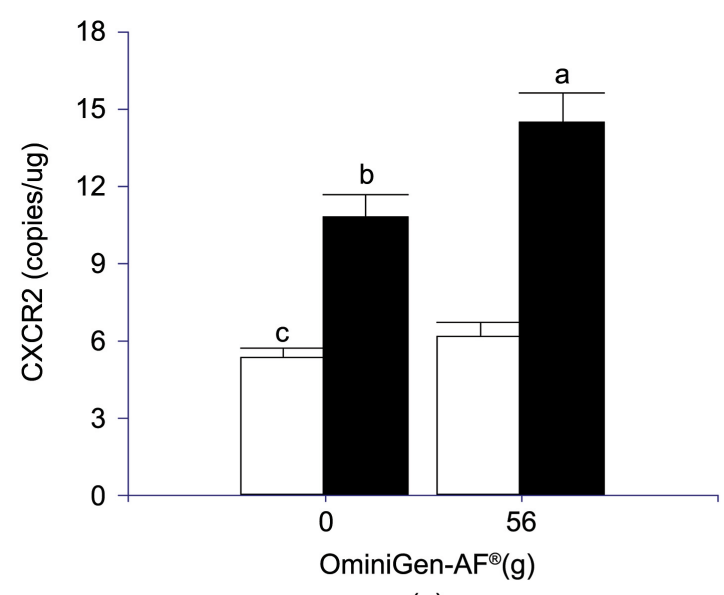

(a)

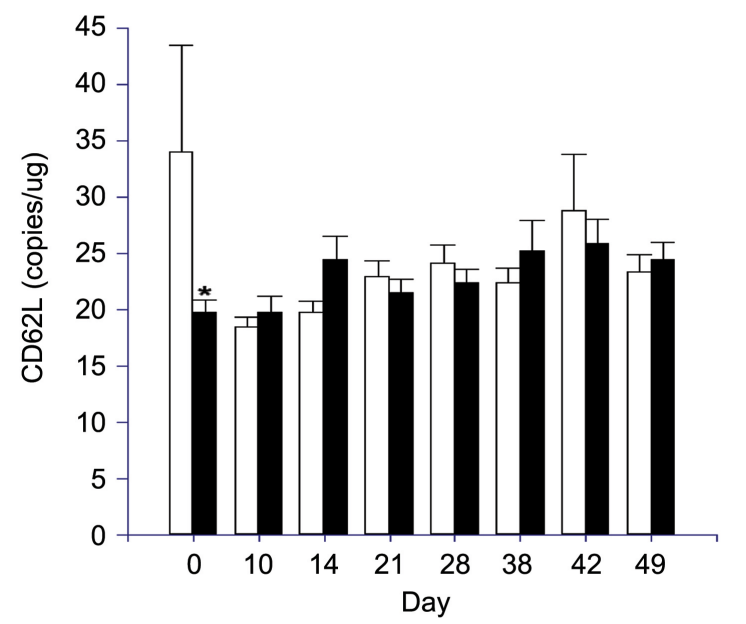

(b)

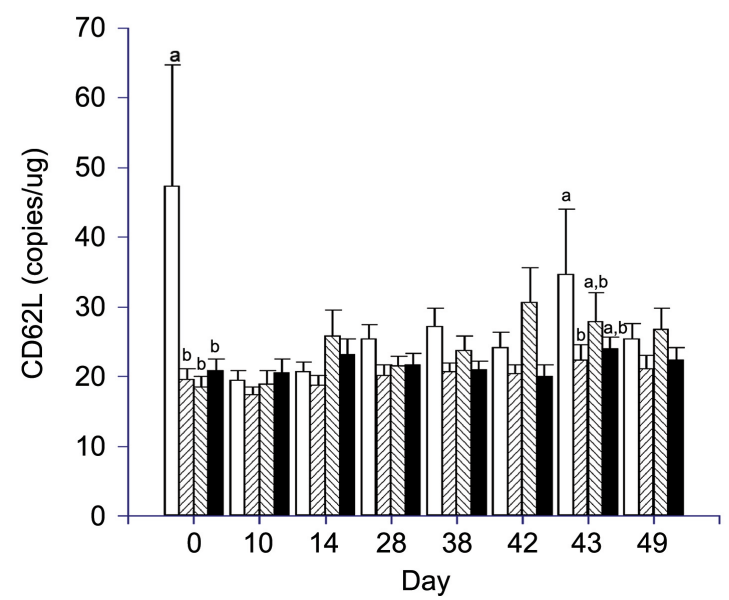

(c)
Replicate

$\square$
$\square$

- 400

Figure 6. Gene expression in cows superovulated with 200 or $400 \mathrm{mg}$ FSH fed 0 or $56 \mathrm{~g}$ OG. (a) CXCR2 expression in cows superovulated with 200 or $400 \mathrm{mg} \mathrm{FSH}$ fed 0 or $56 \mathrm{~g}$ OG in Replicates 1 and 2. (b) CD62L circulating gene expression (means $\pm \mathrm{SE}$ ) in cows superovulated with 200 or $400 \mathrm{mg}$ FSH in Replicates 1 and 2. (c) CD62L circulating gene expression (means \pm SE) in cows superovulated with 200 or $400 \mathrm{mg}$ FSH and fed 0 or $56 \mathrm{~g}$ OmniGen-AF in Rounds 1 and 2; ${ }^{*}$ Different from $C D 62 L$ gene expression in Replicate 1; ${ }^{\mathrm{a}, \mathrm{b}, \mathrm{c}}$ Means without similar superscripts $\operatorname{differ}(P<0.05)$. 
Table 6. CXCR2 and CD62L circulating gene expression ( \pm means) in donor cows superovulated with 200 and $400 \mathrm{mg} \mathrm{FSH}$ and fed 0 and $56 \mathrm{~g}$ OmniGen-AF in Replicates 1 and 2.

\begin{tabular}{|c|c|c|}
\hline Day & CXCR2 (copies/ug) & $C D 62 L($ copies $/ \mu \mathrm{g})$ \\
\hline 0 & $7.3^{\mathrm{c}}$ & 26.6 \\
\hline 10 & $7.4^{\mathrm{c}}$ & 19.1 \\
\hline 14 & $6.7^{\mathrm{c}}$ & 22.2 \\
\hline 21 & $7.4^{\mathrm{c}}$ & 22.1 \\
\hline 28 & $8.4^{\mathrm{b}, \mathrm{c}}$ & 23.2 \\
\hline 38 & $7.7^{\mathrm{b}}$ & 23.8 \\
\hline 42 & $18.8^{\mathrm{a}}$ & 27.2 \\
\hline 49 & $9.9^{\mathrm{b}}$ & 23.9 \\
\hline Pooled SE & 0.9 & 2.0 \\
\hline
\end{tabular}

${ }^{\mathrm{a}, \mathrm{b}, \mathrm{c}}$ Means in the same column without similar superscripts $\operatorname{differ}(P<0.05)$.

CD62L expression in circulating immune cells did not differ $(P>0.10)$ by FSH (200 mg vs $400 \mathrm{mg}, 24.3$ vs 2.8 copies/ $/$ g, respectively; pooled $\mathrm{SE}=1.4$ cop-

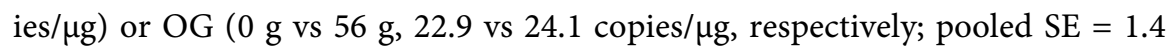
copies/ $\mu \mathrm{g}) . C D 62 L$ expression did not differ by Day (Table 6 ). The FSH $\times$ Day interaction was significant where $C D 62 L$ expression was higher $(P<0.05)$ on Day 0 for cows superovulated with $200 \mathrm{mg}$ FSH compared to cows superovulated with either dose on all remaining days of collection (Figure 6(b)). The FSH $\times$ Replicate $\times$ Day interaction was also significant where CD62L expression was greatest $(P<0.05)$ on Day 0 for cows superovulated with 200 mg FSH in Replicate 1 compared to cows superovulated with either dose in Replicates 1 or 2 on the remaining days of collection (Figure 6(b)). CD62L expression was also greater $(P<0.05)$ on Day 42 in cows superovulated with $200 \mathrm{mg}$ FSH in Replicate 1 compared to cows superovulated with the same dose in Replicate 2 (Figure 6(c)). CD62L expression was not affected by any of the remaining interactions.

\section{Discussion}

Results from this study investigated if two different dosage levels of FSH and feeding OG to mature beef cows altered metabolic parameters, pro-inflammatory cytokines, APP and circulating immune cell gene expression during a superovulation protocol. These treatments did not significantly change the serum concentration or expression of these biomarkers. However, changes in the serum concentration of biomarkers throughout the experimental protocol period were significant and may be useful to monitor cow health and reproductive function when utilizing superovulation. Significant Day effects were observed for changes in serum concentrations for BUN, BHB, NEFA, insulin and glucose during the entire length of the protocol. BHB is a ketone produced by the liver and is an in- 
dicator of energy status in cattle [8]. BHB concentrations were highest on Days 28 and 38 of the protocol, which corresponded to the first injection of PGF and the first dose of FSH, respectively. Throughout this study, $\mathrm{BHB}$ concentrations were within the normal range for beef cattle. BUN is an indicator of rumen undegradable protein (RUP) and increased concentrations can have a negative impact on reproductive performance [26]. BUN concentrations were highest at the start of the trial, dropped and plateaued at the same concentration for the duration of the protocol. These serum concentrations were also within the normal range for beef cattle.

Glucose is a marker for metabolism because it is involved with many different functions of hormone production and is the key nutrient for energy balance for the cow [27]. Glucose is also a nutritional requirement for early embryonic development [28]. In this study, glucose concentrations were highest at the start of the study and on Day 42, the time of the first insemination. Increased glucose concentrations at the time of onset of estrus may be involved with increasing $\mathrm{LH}$ and estrogen production which is allowing for greater ovulatory success, which is when the follicle ruptures to allow for oocyte release [29].

Insulin is another marker for metabolism because it regulates glucose concentrations in the cow and is involved with reproductive performance [30] [31]. Insulin concentrations, like glucose, were highest in Replicate 1, on Day 42. This was somewhat expected because as glucose concentrations increase, the body will begin to secrete insulin to assist with storage in the liver and other organs. There was also an effect of FSH and OG with respect to Replicate. There was no difference in insulin concentration due to FSH dose in Replicate 1. However, in Replicate 2, insulin concentrations were lower in cows receiving 400 compared to $200 \mathrm{mg}$ FSH. Regarding OG feeding, insulin concentrations were low in cows fed $0 \mathrm{~g}$ OG in Replicate 2 and in cows fed $56 \mathrm{~g}$ OG in Replicate 1 . This was interesting, as insulin concentrations were higher in the $0 \mathrm{~g}$ OG fed group in Replicate 1 and in the $56 \mathrm{~g}$ OG fed group in Replicate 2. Overall, insulin concentrations were within the normal range for beef cows.

NEFAs are produced when fat stores are liberated due to low energy input from the diet and can be used as a marker of metabolism. When NEFA concentrations are elevated this causes a decrease in oocyte quality and early embryonic development because NEFAs can penetrate the follicle and hinder oocyte quality [32]. NEFA concentrations were highest on Days 42 and 43 which was during estrus and the peri-ovulatory period of the donor. In the FSH $\times$ OG interaction, cows superovulated with $400 \mathrm{mg}$ FSH and fed $56 \mathrm{~g}$ OG had lower NEFA concentrations compared to cows on the same dose fed $0 \mathrm{~g}$ OG. Cows superovulated with $200 \mathrm{mg}$ FSH and fed $0 \mathrm{~g}$ OG had lower NEFA concentrations than their OG fed counterparts. The difference between the two groups was interesting because NEFA concentrations varied depending on the dose of FSH administered and the amount of OG fed to the cows.

Pro-inflammatory cytokines are important for increasing the inflammatory 
response and increasing the release of APP. IL1- $\beta$ is one of the main pro-inflammatory cytokines, which is involved with promoting inflammation in a target tissue to aid in the immune system response. The results from this study showed IL1- $\beta$ concentration was greatest on Day 49 compared to other days of the study. Day 49 was the day of embryo collection for the donor or Day 7 of gestation. IL1- $\beta$ concentrations were also lower in Replicate1 compared to Replicate 2. This may be due to the second replicate of superovulation inducing a greater inflammatory event because of the challenge previously provided in the first replicate.

IL-6 is a cytokine involved with the pro-inflammatory response. IL- 6 concentrations were lowest on Days 42 and 43 of the protocol. A decrease in IL-6 concentration during this period suggests a decrease in the inflammatory pathway during the time of estrus onset and the peri-ovulatory period. There was also an FSH effect where IL-6 concentrations were lower in cows superovulated with 200 compared to $400 \mathrm{mg}$ FSH. The greater FSH dose may have enhanced the inflammatory response. Similar to IL1- $\beta$, IL-6 concentrations were lower in replicate 1 compared to replicate 2 .

Increased production pro-inflammatory cytokines will lead to elevated concentrations of APP. These are a signal for the inflammatory responses. If concentrations of these proteins are too high, negative effects on ovulation and fertilization can ensue [10]. Albumin is an APP linked to NEFA concentration because it binds and stores NEFA in the liver [33]. Serum albumin was higher on Day 42 compared to all other days and followed a similar trend as other markers. As albumin is a serum binding protein, it is elevated with increased in free steroid hormones, fatty acids and thyroid hormones at the same time in the estrous cycle. Haptoglobin is an APP marker that is produced under elevated concentrations of pro-inflammatory cytokines. Serum haptoglobin concentrations fluctuated during the duration of the superovulation protocol. Periods in the protocol associated with increased handling and injections may have induced an increase in haptoglobin due to stress. SAA is linked to the inflammatory response and is classified as an APP. Serum SAA concentration was greatest on Day 43 compared to the other collection days. Day 43 corresponds to the peri-ovulatory period where the ovarian follicles are preparing to ovulate as part of an inflammation cascade in the ovary.

Previous research demonstrated feeding cows OG resulted in fewer degenerate embryos and a numerical increase in transferrable embryos [22]. Since these differences in embryo quality were observed with OG feeding of the dam, we hypothesized metabolic or inflammatory changes occurred in the dam. While there was no differences attributed to OG feeding or FSH dose on the dam during a superovulation protocol, there were differences observed throughout an estrous cycle. Metabolic changes were observed during a superovulation protocol, which can be attributed to increased number of steroidogenic active follicles on the ovary. Increased metabolic and inflammatory markers in circulation around the 
time of ovulation are important to note, as ovulation is considered to be an inflammatory event [34]. Taken together, this study has demonstrated changes in metabolic and inflammatory markers in normal cycling females.

Overall, replicate emerged as the major factor affecting changes in the metabolic and the immune markers evaluated. Concentrations for the biomarkers of inflammation and metabolism tended to be lower in the first compared to the second replicate of superovulation. These results may indicate the cow response, in terms of metabolic balance and systemic inflammation, may cause increased sensitivity to the superovulation protocol. This could lead to upregulation of the immune and inflammatory response, requiring increased metabolic demands. The implications of these results for embryo quality and reproductive efficiency are not known but could result in a more robust ovarian response. Likewise, the oviduct and uterine environment may prove more receptive for fertilization and embryonic growth during the first days following artificial insemination. The first round of superovulation may have sensitized the donors thereby enabling an augmented response to the second round of FSH dosing and OG feeding. Additional research is needed to fully understand how these specific markers play a role in oocyte quality and early embryonic development.

\section{Acknowledgements}

The authors would like to acknowledge the Oregon Beef Council for providing financial support for this research.

\section{Declaration of Competing Interest}

D. J. McLean was an employee of Phibro Animal Health Corporation when the study was conducted. The authors have no conflict of interest regarding publication of this manuscript.

\section{Conflicts of Interest}

The authors declare no conflicts of interest regarding the publication of this paper.

\section{References}

[1] Bó, G.A. and Mapletoft, R.J. (2014) Historical Perspectives and Recent Research on Superovulation in Cattle. Theriogenology, 81, 38-48. https://doi.org/10.1016/j.theriogenology.2013.09.020

[2] Mapletoft, R.J. and Bó, G.A. (2013) Innovative Strategies for Superovulation in Cattle. Animal Reproduction, 10, 174-179.

[3] Velazquez, M.A. (2011) The Role of Nutritional Supplementation on the Outcome of Superovulation in Cattle. Animal Reproduction Science, 126, 1-10. https://doi.org/10.1016/j.anireprosci.2011.05.009

[4] Walsh, S.W., Mehta, J.P., McGettigan, P.A., Browne, J.A., Forde, N., Alibrahim, R.M., Mulligan, F.J., Loftus, B., Crowe, M.A., Matthews, D., Diskin, M., Mihm, M. and Evans, A.C.O. (2012) Effect of the Metabolic Environment at Key Stages of Fol- 
licle Development in Cattle: Focus on Steroid Biosynthesis. Physiology Genomics, 44, 504-517. https://doi.org/10.1152/physiolgenomics.00178.2011

[5] Diskin, M.G., Mackey, D.R., Roche, J.F. and Sreenan, J.M. (2003) Effects of Nutrition and Metabolic Status on Circulating Hormones and Ovarian Follicle Development in Cattle. Animal Reproduction Science, 78, 345-370.

https://doi.org/10.1016/S0378-4320(03)00099-X

[6] Butler, W.R. (1998) Review: Effect of Protein Nutrition on Ovarian and Uterine Physiology in Dairy Cattle. Journal of Dairy Science, 81, 2533-2539. https://doi.org/10.3168/jds.S0022-0302(98)70146-8

[7] Moussa, M., Shu, J., Zhang, X.H. and Zeng, F. (2015) Maternal Control of Oocyte Quality in Cattle “a Review”. Animal Reproduction Science, 155, 11-27. https://doi.org/10.1016/j.anireprosci.2015.01.011

[8] Beever, D.E. (2006) The Impact of Controlled Nutrition during the Dry Period on Dairy Cow Health, Fertility and Performance. Animal Reproduction Science, 96, 212-226. https://doi.org/10.1016/j.anireprosci.2006.08.002

[9] Turner, M.L., Healey, G.D. and Sheldon, I.M. (2012) Immunity and Inflammation in the Uterus. Reproduction in Domestic Animals, 47, 402-409.

https://doi.org/10.1111/j.1439-0531.2012.02104.x

[10] Ceciliani, F., Ceron, J.J., Eckersall, P.D. and Sauerwein, H. (2012) Acute Phase Proteins in Ruminants. Journal of Proteomics, 75, 4207-4231.

https://doi.org/10.1016/j.jprot.2012.04.004

[11] Abdulrahman, N. and Fair, T. (2019) Contribution of the Immune System to Follicle Differentiation, Ovulation and Early Corpus Luteum Formation. Animal Reproduction, 16, 440-448. https://doi.org/10.21451/1984-3143-AR2019-0087

[12] Sponchiado, M., Gomes, N.S., Fontes, P.K., Martins, T., Del Collado, M., de Assumpcao Pastore, A., Pugliesi, G., Fabio, M., Nogueria, G. and Binelli, M. (2017) Pre-Hatching Embryo-Dependent and -Independent Programming of Endometrial Function in Cattle. PLoS ONE, 12, e0175954. https://doi.org/10.1371/journal.pone.0175954

[13] Boland, M.P., Lonergan, P. and O'Callaghan, D. (2001) Effect of Nutrition on Endocrine Parameters, and Oocyte and Embryo Development. Theriogenology, 55, 1323-1340. https://doi.org/10.1016/S0093-691X(01)00485-X

[14] Wang, Y.Q., Puntenney, S.B., Burton, J.L. and Forsberg, N.E. (2009) Use of Gene Profiling to Evaluate the Effects of a Feed Additive on Immune Function in Periparturient Dairy Cattle. Journal of Animal Physiology and Animal Nutrition, 93, 66-75. https://doi.org/10.1111/j.1439-0396.2007.00780.x

[15] Ryman, V.E., Nickerson, S.C., Kautz, F.M., Hurley, D.J., Ely, L.O., Wang, Y.Q. and Forsberg, N.E. (2013) Effect of Dietary Supplementation on the Antimicrobial Activity of Blood Leukocytes Isolated from Holstein Heifers. Research in Veterinary Science, 95, 969-974. https://doi.org/10.1016/j.rvsc.2013.09.009

[16] Branson, J.A., McLean, D.J., Forsberg, N.E. and Bobe, G. (2016) Yeast-Containing Feed Additive Alters Gene Expression Profiles Associated with Innate Immunity in Whole Blood of a Rodent model. Innate Immunity, 22, 249-256. https://doi.org/10.1177/1753425916640326

[17] Hurley, D.J., Barber, C.E., Adkins, M., Rowson, A.D., Norton, N.A., Nickerson, S.C., Ely, L.O., Kautz, F.M., McLean, D.J. and Chapman, J.D. (2019) An Immunomodulatory Feed Additive Enhances in Vitro Viral Vaccine Recall Antigen Responses in Dairy Heifers. Research in Veterinary Science, 127, 11-17.

https://doi.org/10.1016/j.rvsc.2019.10.002 
[18] Wang, Y., Puntenney, S.B., Burton, J.L. and Forsberg, N.E. (2007) Ability of a Commercial Feed Additive to Modulate Expression of Innate Immunity in Sheep Immunosuppressed with Dexamethasone. Animal, 1, 945-951. https://doi.org/10.1017/S1751731107000365

[19] Hall, L.W., Rivera, F.A., Villar, J.D., Allen, J.D., Chapman, J,D., Long, N.M. and Collier, R.J. (2014) The Effects of OmniGen-AF ${ }^{\circledast}$ on Serum Metabolites, Calcium Concentrations and Hormones of the Adrenal Axis during Heat Stress in Lactating Holstein Cows. Journal of Dairy Science, 97, abstract.

[20] Burdick Sanchez, N.C., Carroll, J.A., Broadway, P.R., Schell, T.H., Puntenney, S.B. and McLean, D.J. (2019) Supplementation of OmniGen-AF Improves the Metabolic Response to a Glucose Tolerance Test in Beef Heifers. Translational Animal Science, 3, 1521-1529. https://doi.org/10.1093/tas/txz130

[21] Casarotto, L.T., Laporta, J., Ferreira, K., Davidson, B.D., Moy, K., Almeida, A.K., Chapman, J.D., McLean, D.J., Kirk, D.J., Barbu, N.I., Ouellet, V. and Dahl, G.E. (2020) Effect of Feeding an Immune Modulator to Multiparous Holstein Cows during the Dry Period and Early Lactation on Health, Milk and Reproductive Performance. Animal Feed Science and Technology, 267, 114527. https://doi.org/10.1016/j.anifeedsci.2020.114527

[22] Snider, A.P., McLean, D. and Menino, A.R. (2019) Effects of Feeding OmniGen-AF on Superovulatory Response in Donor Beef Cows: I. Serum Progesterone and Cortisol, Embryo Recovery and Quality. Animal Reproduction Science, 210, 106174. https://doi.org/10.1016/j.anireprosci.2019.106174

[23] Playford, M.C., Dawson, K., Playford, S.E., Smith, A.N., Page, S.W., Collinsc, K. and Forsberg, N. (2014) Effect of an Immunomodulatory Feed Additive on Markers of Immunity in Pasture-Fed Dairy Cows. Australian Veterinary Journal, 92, 479-481. https://doi.org/10.1111/avj.12269

[24] Armstrong, S. (2016) The Effects of a Dietary Immunomodulatory Supplement on the Immune-Metabolic Axis in Growing Beef Cattle. Oregon State University, Corvallis.

[25] Hall, J.A., Bobe, G., Vorachek, W.R., Kasper, K., Traber, M.G., Mosher, W.D., Pirelli, G.J. and Gamroth, M. (2014) Effect of Supranutritional Organic Selenium Supplementation on Postpartum Blood Micronutrients, Antioxidants, Metabolites, and Inflammation Biomarkers in Selenium-Replete Dairy Cows. Biology Trace Element Research, 161, 272-287. https://doi.org/10.1007/s12011-014-0107-4

[26] Dawuda, P., Scaramuzzi, R., Leese, H., Hall, C., Peters, A., Drew, S. and Wathes, D.C. (2002) Effect of Timing of Urea Feeding on the Yield and Quality of Embryos in Lactating Dairy Cows. Theriogenology, 58, 1443-1455. https://doi.org/10.1016/S0093-691X(02)00973-1

[27] Butler, W. (2000) Nutritional Interactions with Reproductive Performance in Dairy Cattle. Animal Reproduction Science, 60-61, 449-457.

https://doi.org/10.1016/S0378-4320(00)00076-2

[28] Kruse, S.G., Bridges, G.A., Funnell, B.J., Bird, S.L., Lake, S.L., Arias, R.P., Amundson, O.L., Larimore, E.L., Keisler, D.H. and Perry, G.A. (2017) Influence of Post-Insemination Nutrition on Embryonic Development in Beef Heifers. Theriogenology, 90, 185-190. https://doi.org/10.1016/j.theriogenology.2016.11.021

[29] Saifullizam, A.K., Routly, J.E., Smith, R.F. and Dobson, H. (2010) Effect of Insulin on the Relationship of Estrous Behaviors to Estradiol and LH Surges in Intact Ewes. Physiology \& Behavior, 99, 555-561. https://doi.org/10.1016/j.physbeh.2010.01.019

[30] Short, R.E. and Adams, D.C. (1987) Nutritional and Hormonal Interrelationships in 
Beef Cattle. Journal of Animal Science, 17, 29-39. https://doi.org/10.4141/cjas88-003

[31] D’Occhio, M.J., Baruselli, P.S. and Campanile, G. (2019) Influence of Nutrition, Body Condition, and Metabolic Status on Reproduction in Female Beef Cattle: A Review. Theriogenology, 125, 277-284.

https://doi.org/10.1016/j.theriogenology.2018.11.010

[32] Van Hoeck, V., Bols, P.E.J., Binelli, M. and Leroy, J.L.M.R. (2014) Reduced Oocyte and Embryo Quality in Response to Elevated Non-Esterified Fatty Acid Concentrations: A Possible Pathway to Subfertility? Animal Reproduction Science, 149, 19-29. https://doi.org/10.1016/j.anireprosci.2014.07.015

[33] Van Hoeck, V., Sturmey, R.G., Bermejo-Alvarez, P., Rizos, D., Gutierrez-Adan, A., Leese, H.J., Bols, P.E.J. and Leroy, J.L.M.R. (2011) Elevated Non-Esterified Fatty Acid Concentrations during Bovine Oocyte Maturation Compromise Early Embryo Physiology. PLoS ONE, 6, e23183. https://doi.org/10.1371/journal.pone.0023183

[34] Duffy, D.M., Ko, C., Jo, M., Brannstrom, M. and Curry Jr., T.E. (2019) Ovulation: Parallels with Inflammatory Processes. Endocrine Reviews, 40, 369-416.

https://doi.org/10.1210/er.2018-00075 